\title{
Analisis Kelelahan pada Struktur Bravo Wellhead Platform dengan Penambahan Luas Sub-Cellar Deck Menggunakan Metode Cummulative Damage dan Fracture Mechanics
}

\author{
Bagus Panuntun, Nur Syahroni, dan Rudi Walujo Prastianto \\ Departemen Teknik Kelautan, Fakultas Teknologi Kelautan, Institut Teknologi Sepuluh Nopember (ITS) \\ e-mail: baguspanuntun.its@gmail.com
}

\begin{abstract}
Abstrak-Offshore fixed platform didefinisikan sebagai platform yang berada di atas permukaan air dan ditopang Piles dari dasar laut, dan juga lebih sering menerima beban berulang sehingga menyebabkan kelelahan struktur. Kelelahan sturktur merupakan suatu proses dari kumulatif kerusakan yang disebabkan oleh pengulangan fluktuasi beban yang dapat mengakibatkan keruntuhan meskipun beban yang diterima tidak melebihi batas maksimum untuk beban statik. Studi ini bertujuan untuk menganalisis kelelahan struktur Bravo Wellhead Platform yang beroperasi di Selat Madura dengan kedalaman perairan di lokasi tersebut adalah $180.0 \mathrm{ft}$ terhadap MSL (Mean Sea Level). Dalam studi ini penulis menggunakan metode cumulative damage dan fracture mechanics. Pada metode cummulative damage didapatkan umur kelelahan terpendek dibawah MSL sebesar 89,342 tahun pada tubular joint 303. Selanjutnya, dilakukan analisis lokal dan penambahan crack menggunakan metode fracture mechanics terhadap tubular joint 303. Tubular joint paling kritis selanjutnya dianalisis menggunakan metode fracture mechanics dengan memberikan crack sebesar $a=0.25 \mathrm{~mm}, a$ $/ 2 c=0.15$ dan didapatkan umur kelelahannya. Kemudian diketahui selisih umur kelelahan dari kedua metode ini sebesar 22,241 tahun. Kesimpulan dari studi ini adalah retak yang nantinya ditambahkan ke dalam struktur dapat mengurangi service life struktur secara signifikan.
\end{abstract}

Kata Kunci-cumulative damage, fracture mechanics, retak (crack), fatigue life, offshore platform, tubular joint

\section{PENDAHULUAN}

$\mathrm{O}$ FFSHORE fixed platform merupakan anjungan paling tua dan paling banyak dibangun. Struktur offshore fixed platform banyak digunakan dalam eksplorasi migas di Indonesia, khususnya di laut jawa. Suatu offshore fixed platform dikategorikan sebagai anjungan terpancang bila anjungan tersebut dalam operasinya bersifat menahan gayagaya lingkungan tanpa mengalami displacement / deformasi yang berarti. Di laut yang dangkal anjungan dapat dipancangkan ke dasar laut.

Salah satu perusahaan yang mempunyai fasilitas offshore fixed platform adalah perusahaan X di field Poleng. Terdapat beberapa rencana yang akan dikerjakan oleh Perusahaan X untuk meningkatkan kinerja dari eksploitasi minyak dan gas, diantaranya yaitu menambahkan deck di bagian sub-cellar deck seperti pada Gambar 1 pada elevasi (+) 18'-7”, untuk memindahkan equipment Hydro cyclone dari cellar deck. Platform BW di-install pada tahun 1977 dan telah beroperasi selama 41 tahun.
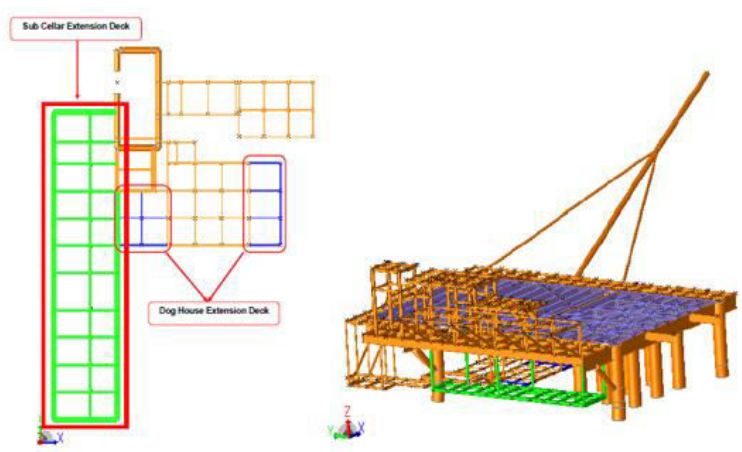

Gambar 1. Rencana penambahan luas sub-cellar deck.

Studi ini akan menganalisis fatigue service life struktur Bravo Wellhead Platform 4 kaki menggunakan metode cummulative damage dan metode fracture mechanics. Perlu diketahui suatu analisis struktur offshore fixed platform berbeda dengan perhitungan struktur di daratan, hal ini dikarenakan banyaknya beban-beban yang lebih kompleks yang menggambarkan suatu kondisi perairan di lokasi kajian.

Analisis ini merupakan suatu cara yang dapat dilakukan untuk memperkirakan risiko terjadinya kerusakan yang diakibatkan oleh beban berulang dan usia dari suatu bangunan dalam menghadapi beban tersebut. Output-nya, akan muncul masa layan atau fatigue service life dari masing-masing sambungan. Analisis fatigue life struktur Bravo Wellhead Platform diawali dengan menganalisis secara global menggunakan metode cummulative damage. Dan joint yang memiliki fatigue life yang kecil akan dianalisis secara lokal. Sehingga mendapatkan nilai stress intensity factor dan besarnya perambatan retak yang digunakan untuk menentukan umur kelelahan dari struktur. Pada akhirnya diketahui selisih hasil perhitungan umur kelelahan yang menggunakan metode cummulative damage dengan metode fracture mechanics. 


\section{DASAR TEORI}

\section{A. Analisis Inplace}

Analisis inplace merupakan tahapan untuk mengetahui kemampulayanan struktur. Adapun tahapan yang dilakukan sebelum melakukan analisis in-place ini adalah :

1. Melakukan permodelan struktur

2. Melakukan input beban-beban yang bekerja

Setelah kedua tahap tersebut dilakukan, maka selanjutnya dilakukan analisis terhadap kemampuan struktur menahan beban yang bekerja.

\section{B. Analisis Fatigue}

Struktur baja yang mengalami fluktuasi tegangan dalam jumlah yang banyak dapat mengalami retak bahkan pada tegangan yang kecil. Fluktuasi tegangan disebabkan oleh beban lingkungan seperti angin dan gelombang, atau getaran dari mesin. Retak kecil dapat berkembang menjadi lebih besar dan dapat mengakibatkan kerusakan struktur. Retak kecil tersebut diakibatkan oleh karena cacat pada bahan, titik dari ketidakhomogenan lokal, dan titik perubahan drastis dari geometri struktur. Struktur yang menggunakan sambungan las juga rentan terhadap fatigue sehingga memerlukan pengawasan yang kontinu.

Berdasarkan API RP 2A $21^{\text {st }}$ edition section 5, pada analisis fatigue struktur dimodelkan sebagai space frame untuk mendapatkan respon struktur berupa tegangan nominal member untuk gaya gelombang yang bekerja. Dengan melakukan analisis fatigue, kita dapat menentukan sisa masa layan dari sambungan las elemen silinder sebuah struktur. Terdapat beberapa parameter yang berhubungan dengan analisis fatigue.

\section{Kurva S-N}

Kurva ini menyediakan informasi karakteristik fatigue dengan amplitudo pembebanan konstan. Kurva S-N yang digunakan berdasarkan API RP2A $21^{\text {st }}$ edition (WSD) section 5.4. ditunjukkan pada gambar berikut [1]:

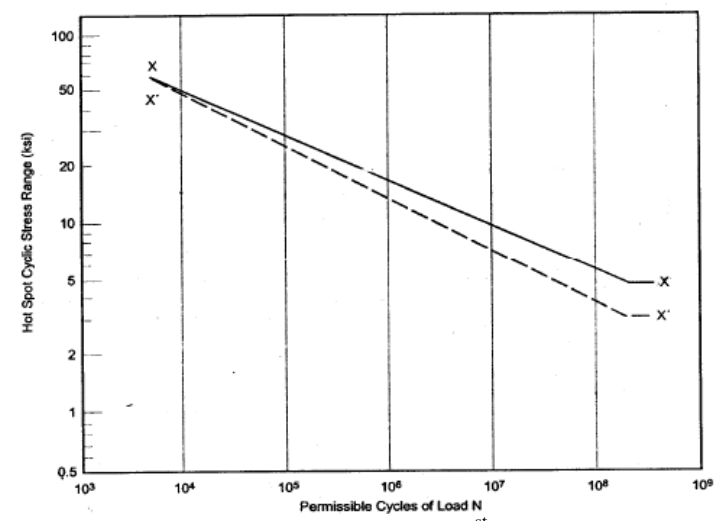

Gambar 2. Kurva S-N berdasarkan API RP2A $21^{\text {st }}$ edition.

\section{Aturan Miner}

Apabila join mengalami pembebanan dengan amplitudo yang bervariasi, siklus pembebanan dapat dibagi menjadi beberapa grup yang memiliki rentang tegangan yang sama. Kerusakan fatigue yang terjadi adalah penjumlahan dari kerusakan fatigue dari masing-masing grup. Aplikasi dari Aturan Miner dapat dirumuskan sebagai berikut :

$\mathrm{D}=\sum_{i=1}^{m} \frac{n_{i}}{N_{i}}$

Dengan :

D : Kerusakan dalam 1 tahun

$\mathrm{n}_{\mathrm{i}}$ : Jumlah siklus pada rentang tegangan yang bekerja pada grup ke-i

$\mathrm{N}_{\mathrm{i}}$ : Jumlah siklus pada rentang tegangan grup ke-i yang diizinkan sesuai kurva S-N

$\mathrm{m}$ : Jumlah pembagian grup rentang tegangan

Kegagalan sambungan struktur akan terjadi apabila nilai persamaan Plamgren-Miner diatas lebih dari 1.

\section{E. Faktor Konsentrasi Tegangan}

Pada kondisi tegangan yang kompleks, terkadang tidak begitu pasti tegangan mana yang harus digunakan untuk kurva S-N. Untuk itu sebuah efek konsentrasi tegangan dapat digunakan pada perhitungan tegangan berupa SCF. Stress Concentration Factor (SCF) adalah perbandingan antara tegangan didaerah hot spot dengan tegangan nominal pada penampang.

Faktor ini dipengaruhi oleh besaran-besaran dari sambungan, konfigurasi sambungan, dan load path gaya. Tegangan daerah hot spot adalah tegangan di sekitar diskontinuitas struktur, contohnya sambungan.
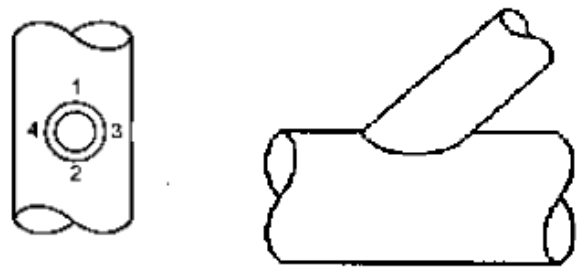

Gambar 3. Ilustrasi daerah yang mengalami tegangan hot spot pada sambungan.

\section{F. Stress Intensity Factor (SIF)}

Parameter yang digunakan untuk fracture toughness salah satunya adalah stress intensity factor (SIF) yang menentukan kepecahan dari materi. SIF adalah satu fungsi tegangan, geometri, dan ukuran retak. SIF dapat diwakili dengan persamaan sebagai berikut:

$\mathrm{K}=\sigma_{\text {nom }} \sqrt{\pi \alpha} f_{(g)}$

dengan:

$\mathrm{K}=$ stress intensity factor ( $\mathrm{ksi} / \mathrm{in})$

$\alpha \quad=$ panjang retak awal

$\sigma$ nom $=$ tegangan nominal

$\mathrm{f}(\mathrm{g}) \quad=$ fungsi koreksi terhadap dimensi, geometri dan posisi retak

\section{G. Perambatan Retak (Crack Propagation)}

Pada kegagalan akibat retakan ditandai dengan munculnya retak awal atau disebut initial crack. Pada tahap ini menjadi indikasi awal terjadinya kegagalan struktur. Perjalanan retakan ini terus berlanjut dengan diikuti perambatan retak yang diakibatkan tegangan geser (micro crack growth stage) yang terus merambat sehingga didominasi oleh adanya tegangan tarik (macro crack growth stage) sampai sisa penampang 
komponen tidak mampu lagi mendukung tegangan kerja hingga patah (final fracture).

\section{H. Analisis Umur Kelelahan}

Hasil perhitungan perambatan retak ini umumnya ditunjukkan sebagai umur kelelahan dari struktur yang ditinjau. Dengan memberikan masukan berupa besar retak awal dan retak akhir akan diketahui jumlah batas siklus yang masih aman dengan mengintegralkan persamaan laju keretakan berikut :

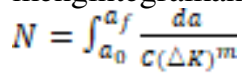

dengan:

$a_{0} \quad=$ panjang retak awal (initial crack)

$N \quad=$ Jumlah cycle

af $\quad=$ panjang retak akhir (final crack)

$\Delta K=$ perubahan stress intensity factor

$\mathrm{C}$ dan $\mathrm{m}=$ konstanta material

\section{METODOLOGI PENELITIAN}

\section{A. Metodologi}

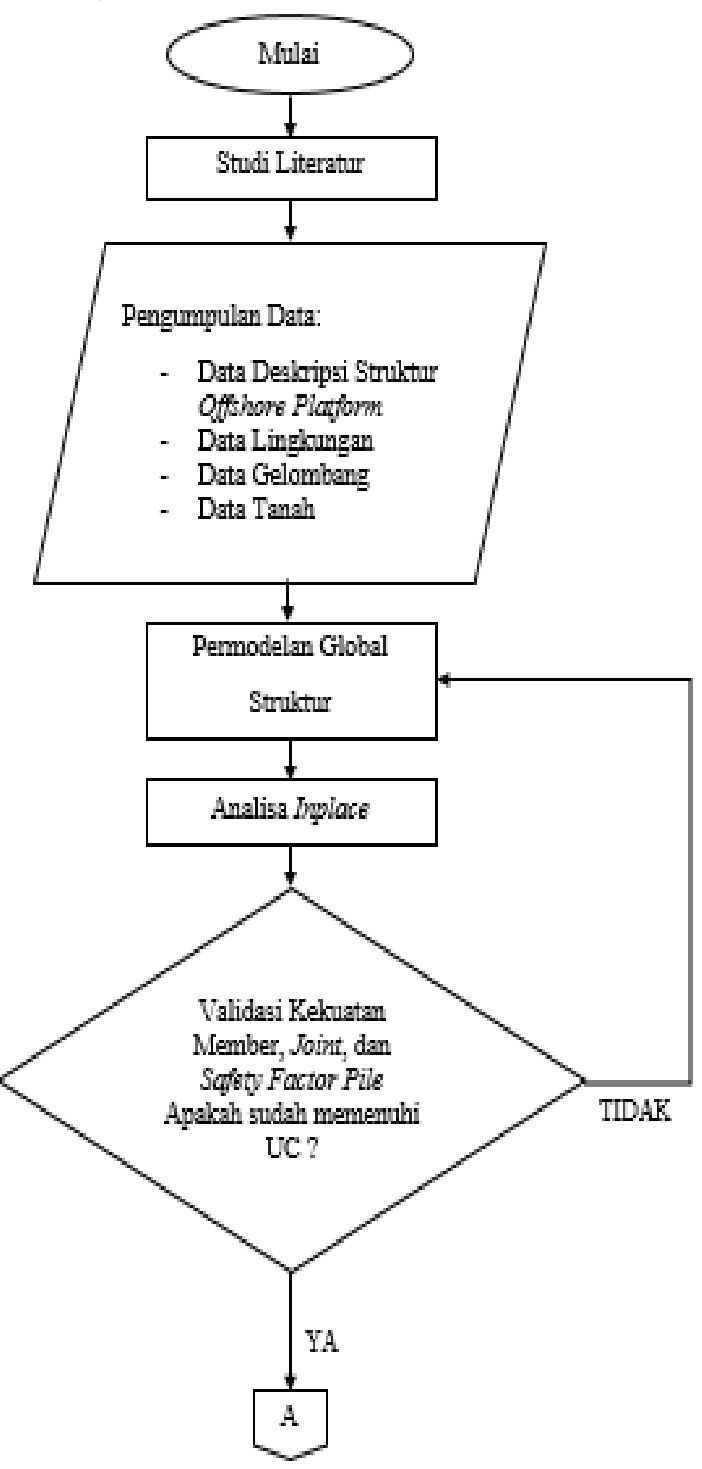

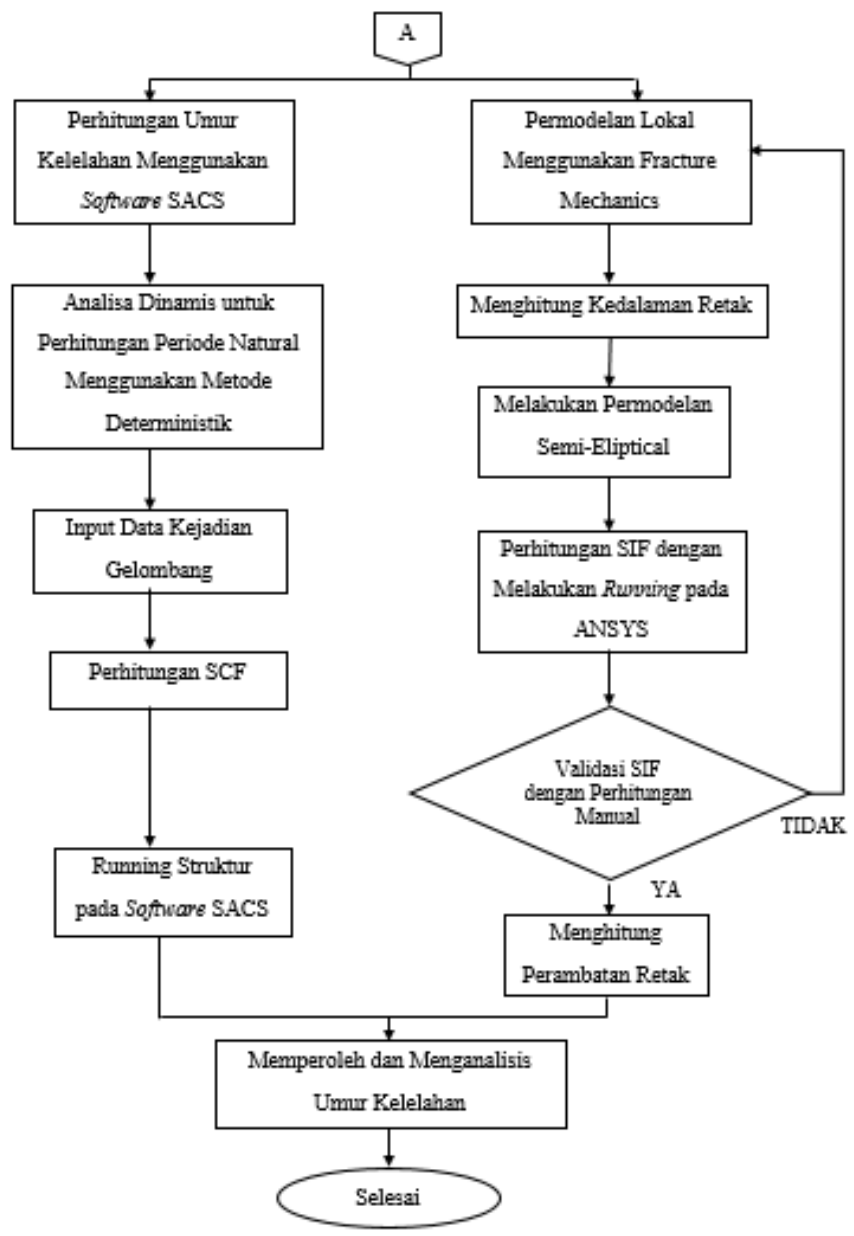

Gambar 4. Diagram Alir Pengerjaan Studi.

\section{B. Data Struktur}

Objek studi yang digunakan oleh penulis adalah Struktur Bravo Wellhead Platform. Bravo Wellhead Platform adalah jaket konvensional berkaki empat.

- Lokasi Platform

Struktur Bravo Wellhead Platform terletak di West Madura Offshore. Koordinat Bravo Wellhead Platform adalah:

-Latitude : 6 $6^{\circ} 41^{\prime} 09.08^{\prime \prime}$ Selatan

-Longitude : $112^{\circ} 54^{\prime} 36.34^{\prime \prime}$ Timur

- Orientasi Platform

"Platform North" harus didefinisikan sebagai arah utara sumbu utama struktur. Perbedaan sudut antara "Platform Utara" dan "True North" adalah 170,7 derajat searah jarum jam.

- Kedalaman Air

Datum referensi adalah Mean Sea Level. Kedalaman air di lokasi adalah $180,0 \mathrm{ft}$ atau sama dengan 54,864 meter.

\section{Jacket}

Jacket terdiri dari 4 kaki dengan dua double battered leg dan dua single battered leg, dengan 30" Piles dalam kaki jacket. Memiliki 5 (lima) jacket horizontal frame, including the jacket walkway. Jaket ini dirancang untuk menampung sump caisson 20 inci dan 3 (tiga) risers, terdiri dari 2 unit 6,625 inci OD dan 1 unit 12,75 inci tabung OD. 


\section{Deck}

Bagian atas Bravo Wellhead Platform didukung dengan 4 kaki dek yang terintegrasi dengan pelat balok. Topside dek memiliki 2 dek tingkat yang terletak di

- Cellar Deck : EL. (+) 29'-0"

- Sub CellarDeck : EL. (+) 18'-7'”

E. Parameter Desain

- Faktor Kontingensi

Kontingensi berat berikut harus digunakan untuk mencakup berat apapun atau beban bervariasi atau ketidakakuratan dalam teknik perancangan.

Tabel 1.

Faktor Kontingensi (Berdasarkan Basis Desain)

\begin{tabular}{|c|c|}
\hline Deskripsi & Kontingensi (\%) \\
\hline Structural Self weight & 5 \\
\hline
\end{tabular}

- Properti Material

Sifat mekanis bajanya adalah:

- Young modulus $\mathrm{E}=29,000 \mathrm{ksi}$,

- Shear modulus $\mathrm{G}=11,600 \mathrm{ksi}$

- Poisson ratio $\quad v=0.3$

- Volumetric mass $\rho=490 \mathrm{lb} / \mathrm{ft}^{3}$

Semua baja struktural yang digunakan dalam penelitian ini harus didasarkan pada spesifikasi berikut dan kekuatan hasil yang sesuai:

Tabel 2.

Spesifikasi Baja Struktural

\begin{tabular}{|c|c|c|}
\hline Deskripsi & Spesifikasi & Yield Stress (ksi) \\
\hline Semua Tubular & ASTM A36 & 36 \\
\hline
\end{tabular}

- Tegangan Ijin

Merangkum tegangan ijin yang dipertimbangkan untuk setiap analisis menurut API RP 2A-WSD :

Tabel 3

Desain Tegangan yang Bekerja

\begin{tabular}{|c|c|c|}
\hline Tipe Analisis & Kondisi & Tegangan Ijin Yang disyaratkan sesuai Pedoman \\
\hline Analisis & Operasi 1 Tahun & Basic AISC-API \\
\cline { 2 - 3 } Struktural & Badai 100 Tahun & Basic AISC-API + $1 / 3$ increase \\
\hline
\end{tabular}

1)

\section{F. Analisis Inplace}

Pada analisis inplace ini penulis melakukan strengthening pada bagian Topside Platform supaya memenuhi kondisi combined unity check lebih kecil dari 1 (UC $<1$ ). Penulis menambahkan dua member tubular dengan properti materialnya ditentukan sebesar OD 6.65" dan WT 0.20 ".

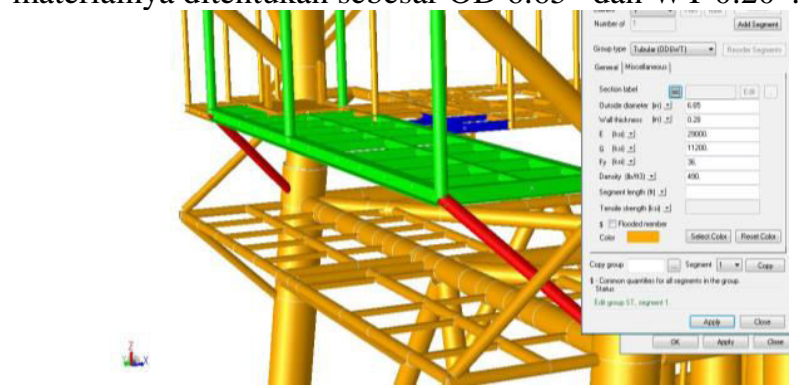

Gambar 5. Strengthening pada Sub-Cellar Deck.

\section{G. Member Stress Check}

Analisis in-place diperiksa di kedalaman air minimum dan kedalaman air maksimum baik untuk kondisi operasi 1 tahun dan kondisi badai 100 tahun. Stress unity checks telah dilakukan sebagai pengganti persyaratan AISC. Tekanan yang diizinkan meningkat $1 / 3$ untuk kondisi badai. Ringkasan member utama ditunjukkan dalam tabel berikut.

Tabel 3 Member Stress Check untuk Analisis In-place in

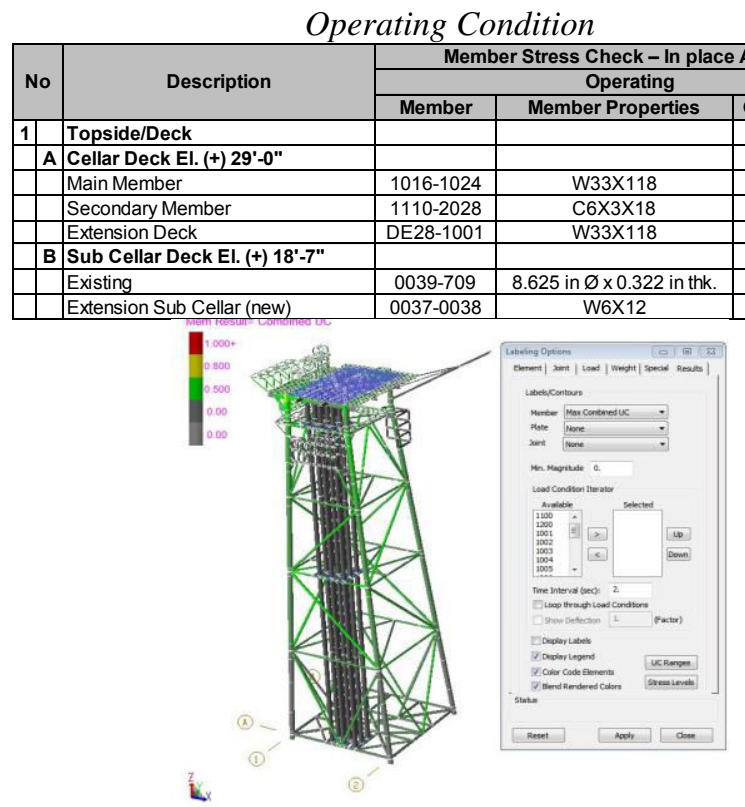

Gambar 6. Member Stress Check struktur untuk Analisis Inplace in Operating Condition

Tabel 4.

Member Stress Check untuk Analisis In-place in Storm Condition

\begin{tabular}{|c|c|c|c|c|c|}
\hline \multirow{3}{*}{ No } & \multirow{3}{*}{ Description } & \multicolumn{4}{|c|}{ Member Stress Check - In place Analysis } \\
\hline & & \multicolumn{4}{|c|}{ Storm } \\
\hline & & Member & Member Properties & Group & UC \\
\hline 1 & Topside/Deck & & & & \\
\hline \multirow[t]{4}{*}{ A } & Cellar Deck El. (+) 29'-0" & & & & \\
\hline & Main Member & $1080-0001$ & W33X118 & W01 & 0,26 \\
\hline & Secondary Member & $1110-2028$ & C6X3X18 & $\mathrm{CH} 2$ & 0,32 \\
\hline & Extension Deck & DE17-1075 & W18X55 & WN2 & 0.46 \\
\hline \multirow[t]{3}{*}{ B } & Sub Cellar Deck El. (+) 18'-7" & & & & \\
\hline & Existing & JW05-8000 & C4X2X9 & MZ1 & 0,52 \\
\hline & Extension Sub Cellar (new) & $0037-0038$ & W6X12 & MP2 & 0,65 \\
\hline
\end{tabular}

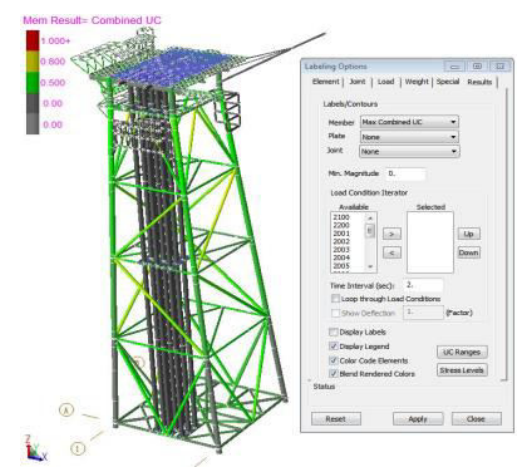

Gambar 7. Member Stress Check struktur untuk Analisis Inplace in Storm Condition.

\section{H. Joint Punching Shear Check}

Punching shear check berdasarkan API RP-2A telah dilakukan untuk semua sambungan (Joints) tubular. Tekanan yang diizinkan ditingkatkan $1 / 3$ untuk kondisi badai menurut 
AISC. Ringkasan punching shear check untuk analisis inplace ditunjukkan pada Tabel 5 dibawah ini.

Tabel 5.

Joint Punching Shear Check untuk Analisis In-place

\begin{tabular}{|c|c|c|c|c|c|}
\hline No. & Load Condition & Joint No. & Load UC & Location & Remark \\
\hline 1 & In-place Operating & 155 & 0.499 & E1. (-) $180^{\circ}$ & Ok \\
\hline 2 & In-place Storm & 145 & 0.989 & E1. (-) $180^{\circ}$ & Ok \\
\hline
\end{tabular}

\section{Faktor Keamanan Pile}

Pile memiliki kapasitas tertentu dalam menahan beban axial yang terjadi. Rasio antara kapasitas aksial pile dengan beban maksimum yang terjadi merupakan nilai safety factor untuk pile. Safety factor untuk kondisi operating disyaratkan minimum 2.0 sedangkan untuk kondisi ekstrem. Ringkasan hasil analisis untuk nilai minimum pile safety factor ditunjukkan pada Tabel 6 dibawah ini.

Tabel 6.

Pile Safety Factor Summary

\begin{tabular}{|c|c|c|}
\hline \multirow{2}{*}{ Pile Head Joint } & \multicolumn{2}{|c|}{ Pile Safety Factor } \\
\cline { 2 - 3 } & Operating & Storm \\
\hline 102 & 3.02 & 1.57 \\
\hline 104 & 3.29 & 1.59 \\
\hline 106 & 4.49 & 1.81 \\
\hline 108 & 3.86 & 1.73 \\
\hline
\end{tabular}

J. Analisis Fatigue Menggunakan Metode Cummulative Damage

Analisis fatigue yang dilakukan dalam studi ini dilakukan dengan cara deterministik (berdasarkan API RP2A). Analisis deterministik sesuai untuk digunakan pada struktur yang memiliki rentang antara perioda natural dan periode gelombang yang cukup lebar.

\section{K. Fatigue Life Member Kritis}

Tabel 7 dibawah ini adalah hasil dari analisis fatigue deterministik, akan didapatkan usia layan dari masing-masing joint pada jacket yang dimodelkan.

Tabel 7.

Hasil Joint dan Member Dengan Umur Kelelahan

\begin{tabular}{|c|c|c|c|c|c|c|}
\hline \multirow[b]{3}{*}{ NO. } & \multirow[b]{3}{*}{ Location } & \multirow[b]{3}{*}{ Joint } & \multirow{3}{*}{$\begin{array}{l}\text { Brace } \\
\text { Member }\end{array}$} & \multicolumn{2}{|l|}{ Struktur } & \multirow[b]{2}{*}{$\begin{array}{c}\text { Fatigue Life } \\
(\mathrm{SF}=2)\end{array}$} \\
\hline & & & & Brace Size & Chord Size & \\
\hline & & & & $(\mathrm{OD} \times \mathrm{WT})$ & $(\mathrm{OD} \times \mathrm{WT})$ & $\begin{array}{l}\text { Service Life } \\
\text { (years) }\end{array}$ \\
\hline 1 & EL (-) 30 & 303 & 303-205 & $16.00^{\prime \prime} \times 0.375^{\prime \prime}$ & $34.00^{\prime \prime} \times 1.00 "$ & 89.342 \\
\hline 2 & EL (-) 180 & 150 & $146-150$ & $16.00^{\prime \prime} \times 0.50^{\prime \prime}$ & $20.00^{\prime \prime} \times 0.50 "$ & 399.865 \\
\hline 3 & EL (-) 30 & 409 & $418-409$ & $14.00 " \times 0.366 "$ & $14.00 "$ x 0.374" & 311.757 \\
\hline
\end{tabular}

L. Analisis Fatigue dengan Menggunakan Metode Fracture Mechanics

Permodelan menggunakan software SOLIDWORK selanjutnya akan di-import ke software ANSYS untuk dilakukan permodelan selanjutnya. Meshing sensitivity adalah proses dimana mengukur keakuratan output dari permodelan ANSYS akibat dari penggunaan jumlah elemen. Jenis elemen yang digunakan adalah solid dengan node tetrahedron.

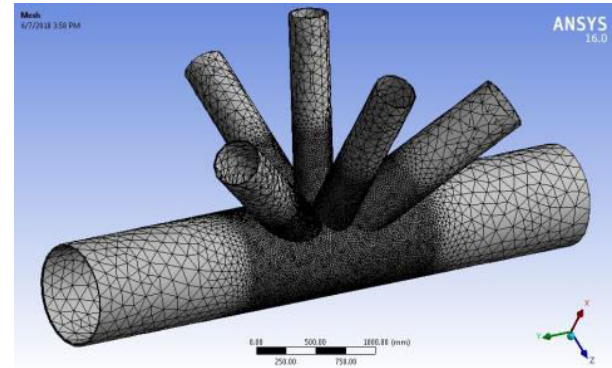

Gambar 8. Meshing Pada Permodelan Analisis Lokal.

\section{Posisi Retak}

Posisi retak awal ditentukan dari konsentrasi tegangan tertinggi yang terjadi. Tegangan tertinggi didapatkan dari penjumlahan tegangan normal dan tegangan geser.. Hasil dari analisis dengan perangkat lunak ANSYS menunjukan tegangan maksimum terjadi pada member 303 - 205 seperti terlihat pada Gambar 9.

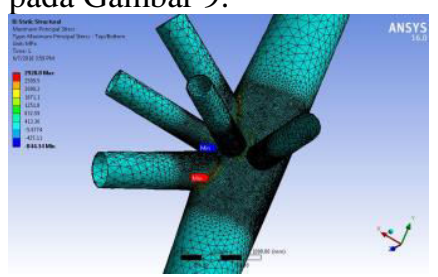

(a)

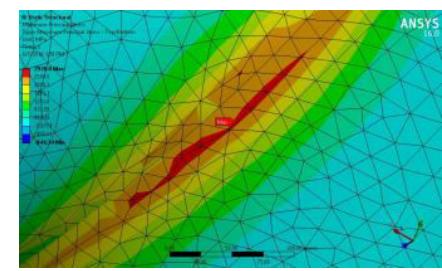

(b)
Gambar 9 (a) Letak Tegangan Maksimum (b) Letak Tegangan Maksimum Tampak Zoom Out.

\section{N. Initial Crack Joint Kritis}

Pada Joint kritis tersebut, akan dimodelkan sebuah surface crack dengan bentuk semi elliptical. Berdasarkan aturan ABS "Guide for Fatigue Assessment of Offshore Structures tahun 2003 kedalaman retak $\left(\mathrm{a}_{0}\right)$ sebesar $0.25 \mathrm{~mm}$ dan perbandingan dari kedalaman retak $\left(\mathrm{a}_{0}\right)$ dengan panjang retak (2c) menggunakan asumsi sebesar $1,67 \mathrm{~mm}$.

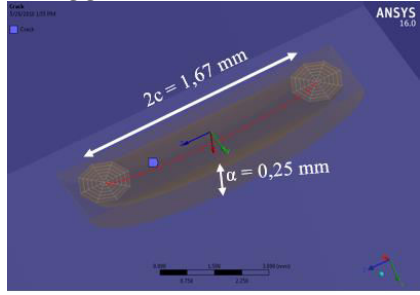

(a) Permodelan Crack Pada Titik Acuan

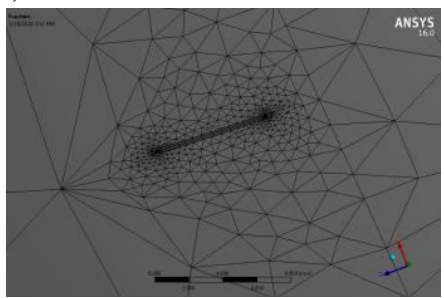

(b) Bentuk Meshing Pada Crack
Gambar 10. (a) Permodelan Crack pada Titik Acuan (b) Bentuk Meshing pada Crack (Lanjutan).

\section{$O$. Perhitungan Umur Kelelahan}

Perhitungan umur kelelahan pada struktur didapatkan dari persamaan berikut:

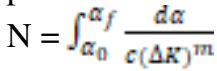

Keterangan:

$\mathrm{a}_{0} \quad=$ Kedalaman Retak Awal (initial crack)

af $\quad=$ Kedalaman Retak Akhir (final crack)

$\mathrm{N} \quad=$ Jumlah Cycle

$\Delta \mathrm{K}=$ Perubahan SIF

$\mathrm{c} \& \mathrm{~m}=$ Konstanta Material 
Dengan menggunakan persamaan-persamaan diatas, maka dapat diperhitungkan umur kelelahan struktur dengan jumlah cycle yang didapatkan kemudian membagi dengan jumlah kejadian cycle pada struktur tersebut seperti pada Tabel 9. Pada Tabel 8 diperlihatkan jumlah cycle yang terjadi agar struktur mengalami kegagalan.

Tabel 8.

Nilai SIF

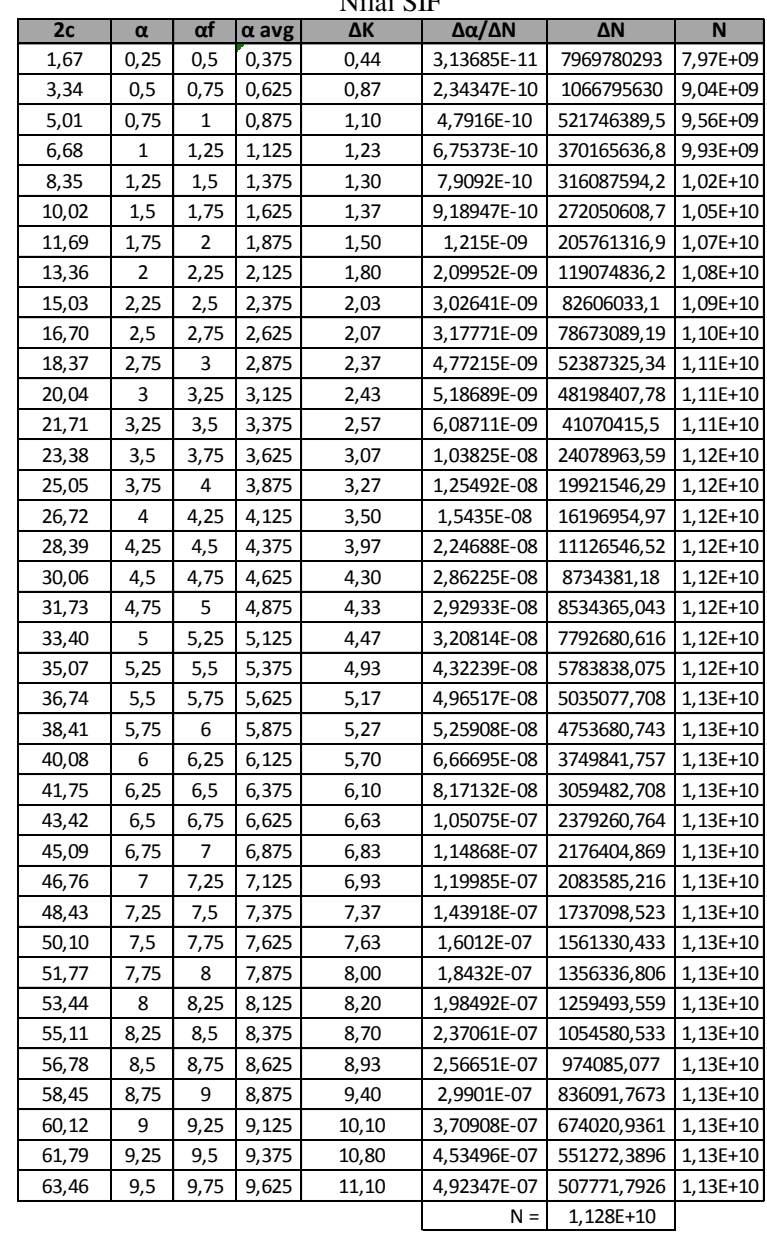

Tabel 9.

Perhitungan umur kelelahan

\begin{tabular}{|c|c|c|c|}
\hline No. & Keterangan & \multicolumn{2}{|c|}{ Nilai } \\
\hline 1 & Jumlah siklus sampai struktur mengalami kegagalan & $1,13 \mathrm{E}+10$ & Siklus \\
\hline 2 & Jumlah kejadian gelombang struktur & $1,68 \mathrm{E}+08$ & Siklus/Tahun \\
\hline & \multicolumn{3}{|c|}{ Perhitungan umur kelelahan struktur } \\
\hline 3 & \multicolumn{3}{|c|}{ Umur Kelelahan Struktur $=\frac{(1)}{(2)}=\frac{1,13 \mathrm{E}+10 \text { siklus }}{1,68 \mathrm{E}+08 \text { siklus } / \text { tahun }}=67,101$ tahun } \\
\hline
\end{tabular}

P. Selisish Umur Kelelahan Menggunakan Metode Cummulative Damage dan Fracture Mechanics

Dari hasil analisis menggunakan metode cummalative damage dan fracture mechanic yang telah dilakukan, maka nilai keduanya dapat digunakan untuk mengetahui nilai perbandingan umur kelelahan platform seperti yang ditunjukkan pada Tabel 10.

Tabel 10.

Selisih Umur Kelelahan Selisih Umur Kelelahan

\begin{tabular}{|c|c|c|}
\hline \multicolumn{3}{|c|}{ Selisih Umur Kelelahan } \\
\hline Metode & Nilai & Selisih \\
\hline Cummulative Damage & 89,342 & \multirow{2}{*}{22,241} \\
\hline Fracture Mechanics & 67,101 & \\
\hline
\end{tabular}

Dapat disimpulkan dari Tabel 10 bahwa selisih umur kelelahan sebesar 22,241 tahun adalah akibat adanya retak di bagian struktur atau platform yang mengakibatkan pengurangan umur kelelahan yang signifikan jika dibandingkan dengan sebelum tidak adanya retak tersebut.

\section{KESIMPULAN}

\section{A. Kesimpulan}

Kesimpulan yang didapat dari analisis umur kelelahan Struktur Bravo Wellhead platform ini antara lain:

1. Kekuatan member unity check terbesar untuk analisis inplace terjadi di area extension sub-cellar dengan nilai UC sebesar 0,74 pada kondisi operasi dan UC sebesar 0,65 pada kondisi badai. Hasil lebih lengkapnya ditampilkan pada Tabel 3 dan Tabel 4.

2. Nilai umur kelelahan Struktur Bravo Wellhead platform pada sambungan joint 303 dengan menggunakan metode cummulative damage ialah sebesar 89.342 tahun..

3. Dengan metode fracture mechanic diperoleh umur kelelahan Struktur Bravo Wellhead platform sebesar $1,1 \mathrm{E}+10$ cycles atau 67,101 tahun. Dan dari perbandingans hasil perhitungan umur kelelahan, dapat disimpulkan bahwa dengan adanya retak mengakibatkan umur kelelahan berkurang signifikan. Pada analisis ini umur kelelahan berkurang 22,241 tahun.

\section{DAFTAR PUSTAKA}

American Petrolim Institute, "Recommended practice for planning, designing and constructing fixed offshore platforms," 1982. 